\title{
Editorial to the special issue
}

\author{
The political economy of the New Fiscalism
}

Marc Lavoie

University of Paris 13 (CEPN), France and University of Ottawa, Canada

Mario Seccareccia

Department of Economics, University of Ottawa, Canada

Fiscal policy witnessed a double U-turn, or policy pirouette, because of the global financial crisis. Prior to the 2008 crisis, all Western governments were defending the need to balance public-sector accounts and target budgetary surpluses. The Canadian government, together with the German government, had perhaps been the most vocal and successful in achieving this fiscal objective, while most governments were emulating one another (at least in their official discourse) and metaphorically were tripping over each other to attain budgetary surpluses. However, after November 2008, all the G20 governments began to run significant discretionary budgetary deficits arising from temporary consumption tax cuts and the extension of unemployment insurance benefits, as well as the decision to engage in large public investments (Auerbach et al. 2010). According to estimates, these stimulus plans in the G20 countries were in the order of about 2 per cent of GDP on average at the time (Antunes et al. 2010: 5). By June 2010, however, Western governments committed themselves once again to reverse their activist fiscal policy position to achieve budgetary balance. In recent years, a slight rift seems to have appeared in the fiscal policy discourse among Western governments of Europe and North America, with the latter somewhat deviating in their commitments to balanced budgets, especially the Canadian government after 2015.

Despite these recent policy differences internationally, according to conventional wisdom, nowadays still popular among a large number of mainstream economists, it would seem that, after the shock and accompanying fears generated by the financial crisis had suddenly tempted so many governments to experiment with Keynesian fiscal policy, the fiscal authorities quickly came to the realization that such policies were misguided. This was so because of their supposed lack of financial sustainability and fears of possible inflationary pressures, thereby reverting once again to the well-worn traditional policy of sound finance. While this is what a good number of mainstream economists are saying, a deeper analysis would suggest that this is not what actually happened. While policymakers in many countries changed their tune and, indeed, subsequently opted for a policy reversal, this was in no way based on a repudiation of what they did. Quite to the contrary, on all occasions they have persistently celebrated their achievement of having combated the economic recession resulting from the financial crisis with their various fiscal stimulus packages! Contrary to the reading of mainstream neoclassical economists, what has actually happened because of the financial crisis is the metamorphosis of fiscal policy into a distinct form, a New Fiscalism - an expression once coined by the late Martin 
Bronfenbrenner (1979). ${ }^{1}$ This new form is neither compatible with the traditional theory of sound finance nor with the Lerner vision of functional finance (see Nell/Forstater 2003).

The fiscal policy consensus prior to the 2008 financial crisis was partly ideologically driven and the outcome of a policy movement in favour of a minimalist state that found its theoretical justification in the classic writings of such economists as Milton Friedman and Friedrich von Hayek. Because of the realpolitik of globalization, this further strengthened the fiscal policy consensus at the time. In the context of globalization, it was said that all that was politically feasible was a more restricted role for the state, thereby necessitating a passive disengagement from important pillars of the Keynesian welfare state. Accompanying this laissez-faire fiscal policy perspective, there also appeared a New Consensus among mainstream economists that monetary policy based on inflation targeting through interest-rate management by the central bank was sufficiently powerful to achieve sustained economic growth and avoid financial instability (Seccareccia 2011/2012; 2012). In this New Consensus framework, fiscal policy could only be destabilizing and useless, as it would crowd-out private investment through higher interest rates (Lavoie 2004). Moreover, in its even more unrealistic version, justified supposedly because of the existence of an inter-temporal budget constraint for the government, deficit spending would squeeze out private consumption, as rational households would somehow seek to cut current consumption out of fear of eventual future tax hikes.

The New Consensus also relied on Friedman's notion of the natural rate of unemployment, revamped in its modern clothes as the vertical Phillips curve associated with the nonaccelerating inflation rate of unemployment (NAIRU), leaving little or no space for active fiscal policy as most mainstream economists believed that public expenditure multipliers were close to zero. On the academic front, in the aftermath of the financial crisis, with austerity policies being unsuccessful and with several countries labouring to come back to their previous GDP level, a number of more eclectic mainstream economists did modify their views. This is exemplified by Blanchard/Leigh's (2013) revision of their assessment of the value of these multipliers, and in the reappearance of arguments based on hysteresis, according to which temporary negative shocks to the economy, such as a financial crisis or deflationary monetary policies, may have permanent negative effects on potential output (Blanchard et al. 2015).

As previously alluded to, the global financial crisis in 2008 radically changed the official policy discourse among policy-makers. Following the meeting of the G20 leaders in Washington in November 2008, there was a sharp reversal of this policy position. With the financial sector crying out for aid, fiscal measures suddenly achieved a level of political legitimacy not seen since the heyday of fiscal intervention of the early post-World War II years. In much the same way, instead of celebrating the virtues of sound finance and fiscal austerity, suddenly Keynesian ideas on the stabilizing role of budget deficits became popular in policy circles. This was so even though the economics profession had undergone no significant revolution in its macroeconomic thinking as had occurred during the 1930s with the publication of Keynes's General Theory. Moreover, with central-bank-controlled

1. Actually, Branson (1989: 383) suggests that an old-line monetarist, David Fand (who had originally engaged in the debates between the Keynesians and Monetarists of the late 1960s and early 1970s) first pinned the term 'fiscalist model' and 'fiscalists', but Branson (1989) does not provide a precise reference. The so-called fiscalists supposedly argued in favour of a vertical IS curve during a recession on the assumption of a short-run interest elasticity of investment being at or close to zero. Indeed, already in the first edition (in 1972) of his Macroeconomic Theory and Policy, Branson made use of the term the 'fiscalists' to describe those promoting fiscal policy activism during a recession. 
nominal interest rates nearing their lower bound (that is, near-zero rates), monetary policy was now considered powerless to combat the crisis.

Hence, for a short period during 2009 and part of 2010, there was a Keynes moment when all governments internationally implemented fiscal stimulus packages largely based on Keynesian demand-side ideas regarding the merits of running budget deficits in times of recession (Lavoie 2010). These ideas, defended by policy-makers, tended to be in strong conflict with the views of most academic economists trained for decades to believe that budget deficits are destabilizing because they would ultimately lead to higher interest rates accompanying higher rates of inflation. Yet, because of force majeure, all governments in the Western world, especially as exemplified by the US government in early 2009, as well as in key developing countries such as China and India, implemented major discretionary fiscal policy changes that pushed public-sector balances strongly into the red. Since early-to-mid 2010, most Western governments, especially on the European continent, abandoned this New Fiscalist policy framework. On the one side, there was significant pressure coming from conservative politicians who were alarmed at the large size of the public-sector deficits and who feared the non-sustainability of the public debt. At the same time, there was pressure from mainstream neoclassical economists who argued that long-term deficits would be destabilizing for the economy (Taylor 2010). Although this view has been severely criticized (see, among others, Arestis/Sawyer 2003 and 2009), policy-makers - particularly in Europe - have reverted to the pre-2008 policy position on the need for an exit strategy and a return to balanced budgets. The position taken by the world leaders at the Toronto Summit of the G20 in June 2010, who had agreed to reverse completely the position taken immediately after the financial crisis in 2008, perhaps best crystallizes this change in policy direction.

However, as pointed out above, this was not a recantation, since many of the world's policy-makers argued that the previous budgetary deficits had achieved their objectives. We wish to argue that, in contrast to the pre-financial-crisis era, there has been a return by policy-makers to a greater degree of fiscal policy pragmatism, based on the functionality of deficit spending rather than a return to the ideologically driven orthodox view that governments should continually strive towards budgetary balances regardless of the macroeconomic conjuncture. One observes this best by the fiscal policy actions taken by North American governments in recent years that continue to run significant budgetary deficits, which, in so doing, have pulled those economies more quickly out of secular stagnation than those on the European continent. On the other hand, neither have policymakers fully espoused Abba Lerner's position in support of functional finance. It is this hybrid view that we have described as the New Fiscalism. Our analysis of this distinct fiscalist policy framework that took shape during the global financial crisis gave rise to a research project that we proposed to the Social Sciences and Humanities Research Council of Canada (SSHRC) and to the Institute for New Economic Thinking (INET). The four papers published in this special issue are just a part of the output that arose from this endeavour and that were generously supported by these funding agencies from 2011 to 2015 .

The first paper, by Brett Fiebiger, examines what has been the position of some of the main economists at the Bank for International Settlements (BIS), whom he associates with what he calls the New Austrian School, due to its close ties with some of the ideas defended by Friedrich von Hayek and the Old Austrian School. Fiebiger shows that BIS authors such as Claudio Borio or Bill White have always been critical of the New Consensus, as they never believed that inflation targeting would be sufficient to avoid macroeconomic instability or the development of asset inflation through unfettered bank credit. Fiebiger reveals that these authors have accepted aspects of the financial instability hypothesis of Hyman Minsky, as they fear that the current overly low rates of interest form the seeds of another financial 
crisis. At the same time, unlike Minsky, many of them reject the notion of Keynesian demand management, believing that it would have been best to have let the recession run its course. Fiebiger closes his article with a critique of the BIS notion of financial imbalances, introduced as a replacement for the traditional output gap, which BIS authors consider misleading.

The second paper, written by Brett Fiebiger and Marc Lavoie, deals with the evolution of the position held by the International Monetary Fund (IMF), and the influence it had on G20 communiqués, before, during and after the global financial crisis. They describe the various U-turns taken by this key international institution and some of its economists. They show that the IMF is, in some way, an exemplar of the New Fiscalism view, as it went through a cycle of acceptance and doubts about the appropriateness of Keynesian demand management. Fiebiger and Lavoie argue that the IMF took a highly pragmatic view, a sort of New Fiscalism Mark II, where countries that have sufficient 'fiscal space' (whatever that means, either politically or financially) should be encouraged to pursue expansionary fiscal policies in particular, in order to help generate greater aggregate effective demand in the countries that lack such space. This and the IMF's moderate support for wage-led growth policies ran into some confrontation with European bureaucrats.

The role of the European Commission is precisely the subject tackled by Orsola Costantini in the third paper of this special issue. Costantini analyses the evolution of the fiscal rules imposed on the members of the European Union, starting with the Maastricht Treaty. She claims that the cyclically adjusted budget $(\mathrm{CAB})$ constraint eventually adopted by the Commission is the result of a compromise, tying together the desire for rigid rules with the need to have some flexibility in dire circumstances. She further argues that the $\mathrm{CAB}$ estimates are shaky despite their apparent technicity, being highly sensitive to timeseries updates and relying on a supply-side view of the economy, based on estimates of potential output or of a NAIRU, which are averages of past values. Costantini concludes by contending that because of these new fiscal rules, the locus of political negotiation now resides with technocratic committees.

The fourth paper is by Mario Seccareccia. He asks whether it is still possible for European policy-makers to achieve a high level of employment through concerted fiscal policy action or whether the structural design flaw of the eurozone makes this impossible. To help provide an answer, Seccareccia examines the events that occurred between 2008 and 2010, when governments in Europe did indeed pursue concerted expansionary fiscal policies for a short while, as a response to the global financial crisis, without triggering the sovereign debt crisis that ensued in the eurozone after 2009. After a close examination of the various explanations offered for the specific 2010-2012 eurozone crisis, he concludes that the European Monetary Union has a faulty design, intentionally constructed in this way to provide a built-in deflationary bias that would restrain wage growth and prevent strong counter-cyclical responses to deflationary shocks. Seccareccia maintains that a modern economy founded on a constitutional separation between money and the state cannot but be inherently dysfunctional and crisis-ridden.

\section{REFERENCES}

Antunes, P., Browarski, S., Stewart, M. (2010): Lessons from the Recession and Financial Crisis: Lesson 5 - Sound Fiscal Policy is Key to Keeping the Economy Afloat in Hard Times, Executive Action Brief, March, Ottawa: Conference Board of Canada, URL: http:/www.acec.ca/files/advocacy/ vi/Lessons $\% 20$ From $\% 20$ the $\% 20$ Recession $\% 20$ and $\% 20$ Financial $\% 20$ Crisis $\% 20-\% 20$ Confer ence $\% 20$ Board\%202010.PDF.

Arestis, P., Sawyer, M. (2003): Reinventing fiscal policy, in: Journal of Post Keynesian Economics, 26(1), 3-25. 
Arestis, P., Sawyer, M. (2009): The intertemporal budget constraint and the sustainability of budget deficits, in: Creel, J., Sawyer, M. (eds), Current Thinking on Fiscal Policy, Basingstoke, UK: Palgrave Macmillan, 95-111.

Auerbach, A.J., Gale, W.G., Harris, B.H. (2010): Activist fiscal policy, in: Journal of Economic Perspectives, 24(4), 141-164.

Blanchard. O., Leigh, L. (2013): Growth forecast errors and fiscal multipliers, International Monetary Fund, working paper 13/1, URL: https://www.imf.org/external/pubs/ft/wp/2013/wp1301.pdf.

Blanchard, O., Cerutti, E., Summers, L. (2015): Inflation and activity: two explorations and their monetary implications, NBER working paper 21726, URL: http://www.nber.org/papers/ w21726.pdf.

Branson, W.H. (1989): Macroeconomic Theory and Policy, 3rd edn, New York: Harper \& Row.

Bronfenbrenner, M. (1979): Macroeconomic Alternatives, Arlington Heights, IL: AHM Publishing.

Lavoie, M. (2004): The new consensus on monetary policy seen from a post-Keynesian perspective, in: Lavoie, M., Seccareccia, M. (eds), Central Banking in the Modern World: Alternative Perspectives, Cheltenham, UK and Northampton, MA: Edward Elgar, 15-34.

Lavoie, M. (2010): Are we all Keynesians?, in: Revista de Economia Politica [Brazilian Journal of Political Economy], 30(2), 189-200.

Nell, E.J., Forstater, M. (eds) (2003): Reinventing Functional Finance, Cheltenham, UK and Northampton, MA: Edward Elgar.

Seccareccia, M. (2011/2012): The role of public investment as principal macroeconomic tool to promote long-term growth: Keynes's legacy, in: International Journal of Political Economy, 40(4), 62-82.

Seccareccia, M. (2012): Understanding fiscal policy and the New Fiscalism, in: International Journal of Political Economy, 41(2), 61-81.

Taylor, J.B. (2010): Getting back on track: macroeconomic lessons from the financial crisis, in: Federal Reserve Bank of St. Louis Review, 92(3), 165-176. 